\title{
Anti-EGFR Monoclonal Antibody SYN004
}

National Cancer Institute

\section{Source}

National Cancer Institute. Anti-EGFR Monoclonal Antibody SYNOO4. NCI Thesaurus. Code C121550.

A g lyco-eng ineered monoclonal antibody directed ag ainst the receptor tyrosine kinase epidermal growth factor receptor (EGFR), with potential antineoplastic activity. Upon administration, anti-EGFR monoclonal antibody SYN004 binds to the extracellular domain of EGFR, which prevents ligand binding and the subsequent activation and dimerization of the receptor. This inhibits the activation of EGFR-mediated signaling pathways and inhibits EGFR-dependent tumor cell proliferation. EGFR, a member of the EGFR receptor tyrosine kinase family, may be overexpressed on the cell surfaces of various tumor cell types. 